\title{
Morphometric and High Resolution Scanning Electron Microscopy Study of Calomys callosus Major Palatine Nerve
}

\author{
Estudio Morfométrico y Electrónico de Barrido de Alta Resolución \\ del Nervio Palatino Mayor del Calomys callosus \\ "Maurício Tanisaki; ** Koichi Ogawa; ${ }^{* * *}$ Rita de Cássia Ribeiro da Silva Lapa; \\ ${ }^{* * * * *}$ Marcelo Cavenaghi Pereira da Silva $\&{ }^{* * * * *}$ Ii-sei Watanabe
}

TANISAKI, M.; OGAWA, K.; LAPA, S. R. C.; DA SILVA, P. M. C. \& WATANABE, I. Morphometric and high resolution scanning electron miccroscopic study of Calomys callosus major palatine nerve. Int. J. Morphol., 23(1):13-18, 2005.

SUMMARY: The characteristics of Calomys callosus major palatine nerve were studied employing light, transmission and high resolution scanning electron microscopy methods. For light microscopy, the specimens were fixed in Bouin's fixative solution, processed routinely and the sections were stained with hematoxylin-eosin and Azo-Carmin to identify nerve fibers. For high resolution scanning electron microscopy the O-D-O method reported by Tanaka (1989) was used to examine nerve fiber components and to measure the myelin sheath. Thin sections were examined by transmission electron microscopy to show axoplasmic elements and adjacent structures. The results revealed nerve fiber bundles in the lamina propria of Calomys callosus palatine mucosa. Nerve fibers were enveloped by cytoplasmic lamellae of perineural cells and adjacent collagen bundles, their diameter ranged from 1 to $6 \mu \mathrm{m}$, and the myelin sheath ranged from 0.2 to $0.9 \mu \mathrm{m}$. In the nerve fibers axoplasm were seen neurofilaments, mitochondria, neurotubules and few unmyelinated fibers.

KEY WORDS: Major palatine nerve; HRSEM; TEM; Calomys callosus; Myelin sheath; Morphometric.

\section{INTRODUCTION}

Studies concerning the characteristics of oral structures nerve fibers are relatively few. The predominance of unmylinated fibers in mouse petrosal nerves was reported by Shimozawa $(1971,1972)$ and in the mouse pterygoid canal nerve by Shimozawa (1973). On the other hand, Foley (1947) demonstrated that in the petrosal nerve of dog and cats were present more myelinated fibers. Watanabe (1981) reported that mouse inferior alveolar nerve contains a great number of thick myelinated fibers and few unmyelinated fibers enveloped by Schwann cell cytoplasmic sheath. Employing the silver impregnation method, Watanabe \& König (1977) reported that the palatine mucosa of Cebus apella monkey presents an innervation containing numerous nerve fibers of different diameters.

Ultrastructurally, the lamellar encapsulated nerve endings of rats and guinea pig palatine mucosa are enveloped by bundles of collagen fibers (Watanabe \& Yamada, 1983,
1985). This paper aims to show the morphological aspects and three-dimensional images of Calomys callosus palatine nerve using light, transmission, high resolution scanning electron microscopic and morphometric methods.

\section{MATERIAL AND METHOD}

Sixteen adult Calomys callosus of both sexes weighing 30 to $50 \mathrm{~g}$ were used. The animals were anaesthetized intraperitoneally using pentobarbital sodic solution $(5 \mathrm{ml} / \mathrm{kg})$ and perfused with $2 \%$ paraformaldehyde. For light microscopy preparation the palatine mucosa was removed and immersed in Bouin solution for $48 \mathrm{~h}$ and then, the tissues were washed in distilled water. The tissues were dehydrated in increasing series of ethanol, and embedded in paraffin. Sections of $6 \mu \mathrm{m}$ were obtained and stained with

* Department of Anatomy, University of São Paulo, Brazil.

** Department of Anatomy, University of Fukuoka, Japan.

*** Department of Histology, University Federal of São Paulo, Brazil.

**** Department of Anatomy, São Leopoldo Mandic Research Center, Campinas, Brazil.

***** Full Professor, Department of Anatomy, University of São Paulo, Brazil. 
Azo-Carmim and hematoxylin-eosin to examine nerve fiber bundles. Tissues were analyzed in a Zeiss photomicroscopy apparatus.

For high resolution scanning electron microscopy (HRSEM), Calomys callosus palatine mucosa was fixed by immersion in $2 \%$ osmium tetroxide in $1 / 15 \mathrm{M}$ phosphate buffer ( $\mathrm{pH} 7.4$ ) at $4^{\circ} \mathrm{C}$ for $2 \mathrm{~h}$ according to the technique reported by Tanaka (1989). Then, the tissues were rinsed in distilled water overnight and after that were immersed in $12.5 \%, 25 \%$ and $50 \%$ dimethyl sulfoxide (DMSO) solutions for 30 minutes each. They were frozen in liquid nitrogen and fractured with TF-2 Eiko apparatus. The fractured specimens were placed in a 50\% DMSO solution and rinsed in distilled water, and then, they were macerated in $0.1 \%$ osmium tetroxide for $48 \mathrm{~h}$ at $22^{\circ} \mathrm{C}$ (Tanaka, 1989; Watanabe et al., 1992, 1996, 1997). After rinsing in distilled water, they were postfixed in $2 \%$ osmium tetroxide for $2 \mathrm{~h}$ at $4{ }^{\circ} \mathrm{C}$, rinsed and treated with a $2 \%$ tannic acid solution for $1 \mathrm{~h}$ at room temperature. The dehydration of samples was made in an increasing series of ethanol and t-butyl alcohol and dried in Balzers CPD-030 or Eiko CPD-II. The dried tissues were mounted on a gold plate with carbon paste and coated with Hitachi, ID-2 Eiko apparatus. The samples were examined in a high resolution scanning electron microscope (HRSEM) Hitachi, S-900 at $10 \mathrm{kV}$ at Department of Anatomy, School of Medicine Fukuoka University, Japan.

For transmission electron microscopy (TEM), the specimens were fixed in modified Karnovsky solution containing $2.5 \%$ glutaraldehyde and $2 \%$ paraformaldehyde in sodium phosphate buffer $0.1 \mathrm{M}$ at $\mathrm{pH}$ 7.4. Then, the tissues were postfixed in $1 \%$ osmium tetroxide solution during $2 \mathrm{~h}$ at $4^{\circ} \mathrm{C}$, dehydrated in an increasing series of ethanol and propylene oxide and embedded in Spurr resin, according to Watanabe et al. (1997). Thick sections were made and stained with toluidin blue solution for selection of interest area under light microscopy. Thin sections were made, counterstained with uranyl acetate and lead citrate and examined in transmission electron microscopy Jeol, 1010 at $80 \mathrm{kV}$ at Institute of Biomedical Sciences, University of São Paulo.

\section{RESULTS}

Palatine nerve bundles were located in the deep region of Calomys callosus palatine mucosa (Fig. 1). The lamellae of perineural cell sheath and adjacent collagen bundles were revealed surrounding the nerve fibers.

The macerated samples in diluted osmium tetroxide showed a general view of myelinated nerve fibers (Fig. 2) which were surrounded by laminae of collagen fibers (Fig. 3). In high magnification, the presence of collagen fibers of endoneurium was clearly seen (Fig. 4). Thickness of myelin sheath ranged from 0.2 to $0.9 \mu \mathrm{m}$, and the medium was 0.55 $\mu \mathrm{m}$. The diameter of nerve fibers of palatine nerve was between 1 to $6 \mu \mathrm{m}$, being more frequent between 2 and 4 $\mu \mathrm{m}$. The nerve fiber medium diameter was $3.48 \mu \mathrm{m}$. The histograms 1 and 2 revealed the frequency of myelin sheath thickness and palatine nerve fibers diameter.

Basal lamina nerve fibers were characterized by the presence of a sponge-like structure and fine collagen fibrils (Fig. 5). Transmission electron microscopy revealed that nerve fiber bundles contain myelinated fibers intermingled by few unmyelinated fibers of small diameters (Fig. 6). The Schwann cell lamina enveloped each nerve fiber and in the axoplasm was noted the meshwork of neurofilaments, mitochondria and neurotubules (Figs. 7 and 8).

\section{DISCUSSION}

The present paper demonstrated ultrastructural aspects and three-dimensional characteristics of Calomys callosus major palatine nerve fibers employing light, transmission and high resolution scanning electron microscopic methods.

According to our observations the nerve bundles are constituted by thick and thin nerve fibers enveloped by collagen fibers of endoneurium. These characteristics were clearly observed in the HRSEM samples, identifying the collagen fibers in three-dimensional images. Our TEM data also demonstrated that the perineural cells presented lamellae of cytoplasmic extensions. These structures confirmed the findings reported by Watanabe \& König (1977) in the palatine mucosa of Cebus apella monkey. It is interesting to emphasize that thick and thin nerve fibers were more often in the palatine rugae subepithelial region.

Based on our results, it is possible to confirm that there are numerous nerve endings resulting from ramifications of palatine nerve fibers. Kubota et al. (1963), Kubota \& Hayama (1964), Kubota (1966), Kubota \& Togawa (1966) reported that nerve terminals of different shapes supply the connective tissue papillae. Ohgaki (1953) demonstrated that the complexity of nerve terminals depend on the type of ramification and this was also reported by Ogasawara et al. (1954), and Gairns $(1954,1955)$ in the palatine mucosa.

Our data revealed that the bundles of myelinated and 

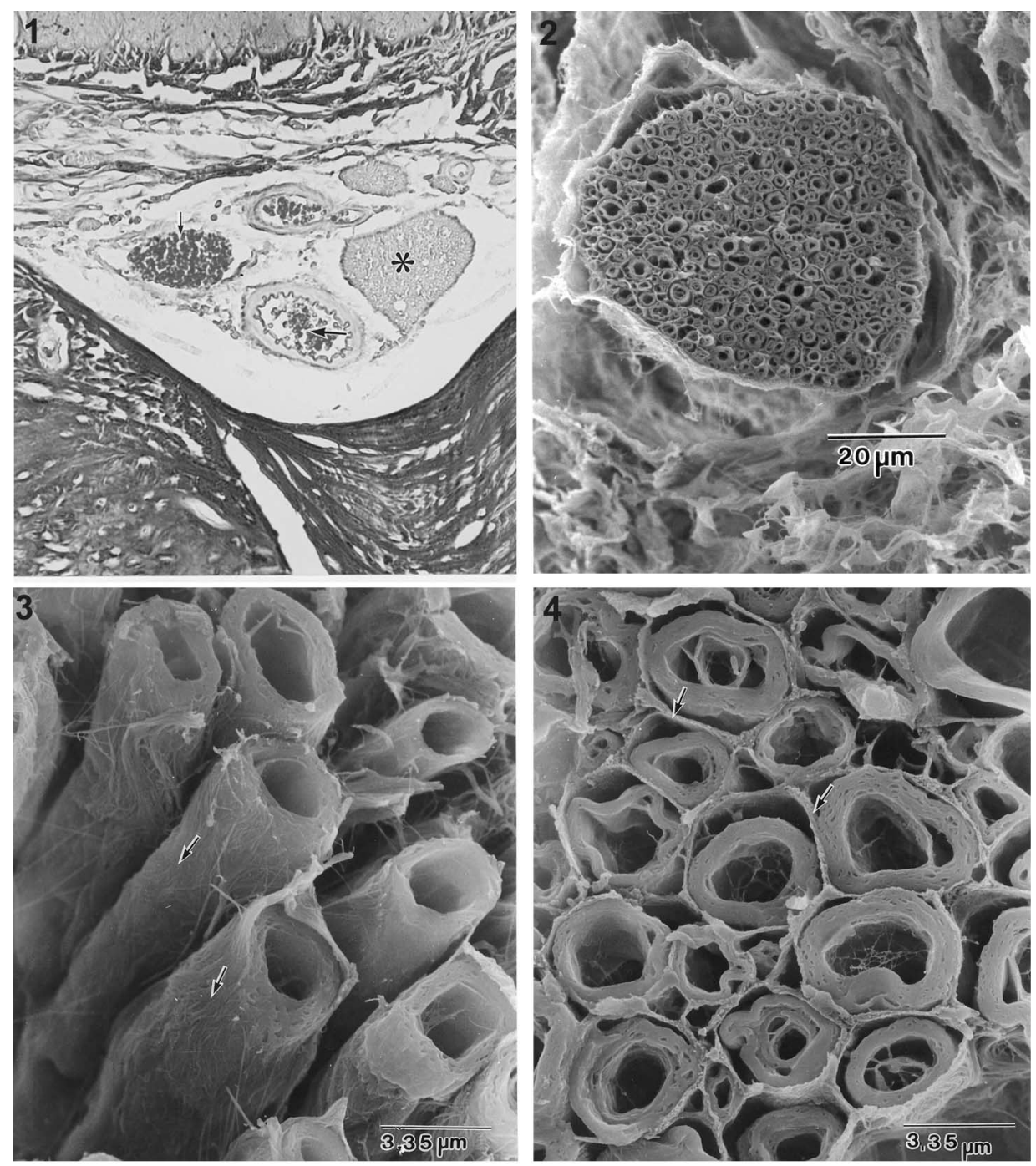

Fig. 1 Light microscopy showing the presence of palatine nerve $(*)$ and vessels. Artery (large arrow), vein (small arrow) and nerve. Azo-Carmin X60.

Fig. 2 Specimen fixed in $2 \%$ osmium tetroxide and fractured in DMSO. Shows the surface with numerous nerve fibers. X700.

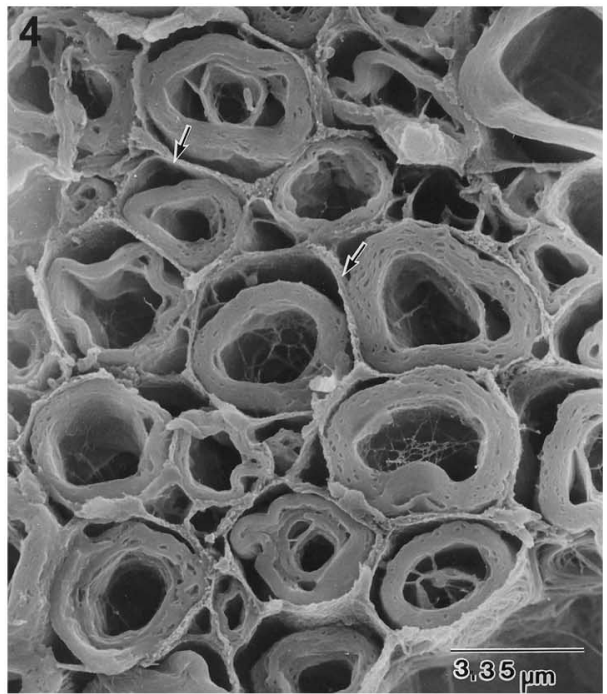

Fig. 3 Macerated sample showing the nerve fibers with collagen fibers (arrows) of endoneurium. X3.900.

Fig. 4 Three-dimensional HRSEM images of transversally fractured nerve fibers revealing the thickness of myelin sheath, neurofilaments, and bundles of collagen fibers of endoneurium (arrows). X4.200.

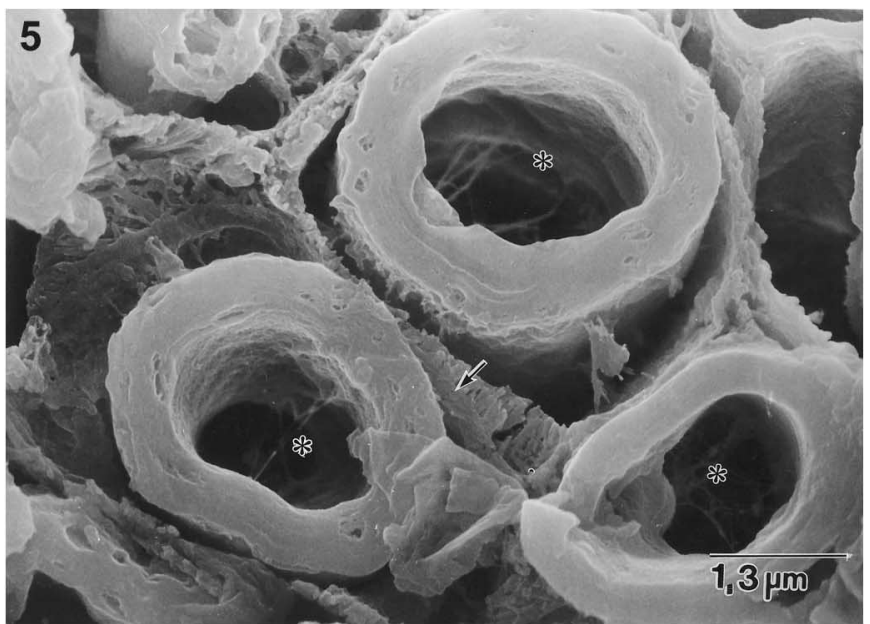

Fig. 5 At high magnification of HRSEM image shows the nerve fibers $(*)$, thickness of myelin sheath, and endoneurium collagen fibers (arrows). X10.800.

unmyelinated subepithelial nerve fibers are surrounded by cytoplasmic lamellae of perineural cells and adjacent collagen fibers. The interpretation of different thickness of myelin sheath and lamella of perineural cells are not yet completely defined. These data certainly will contribute to the functional - morphology comprehension but other experiments are necessary to confirm details of the nerve conduction mechanism. 

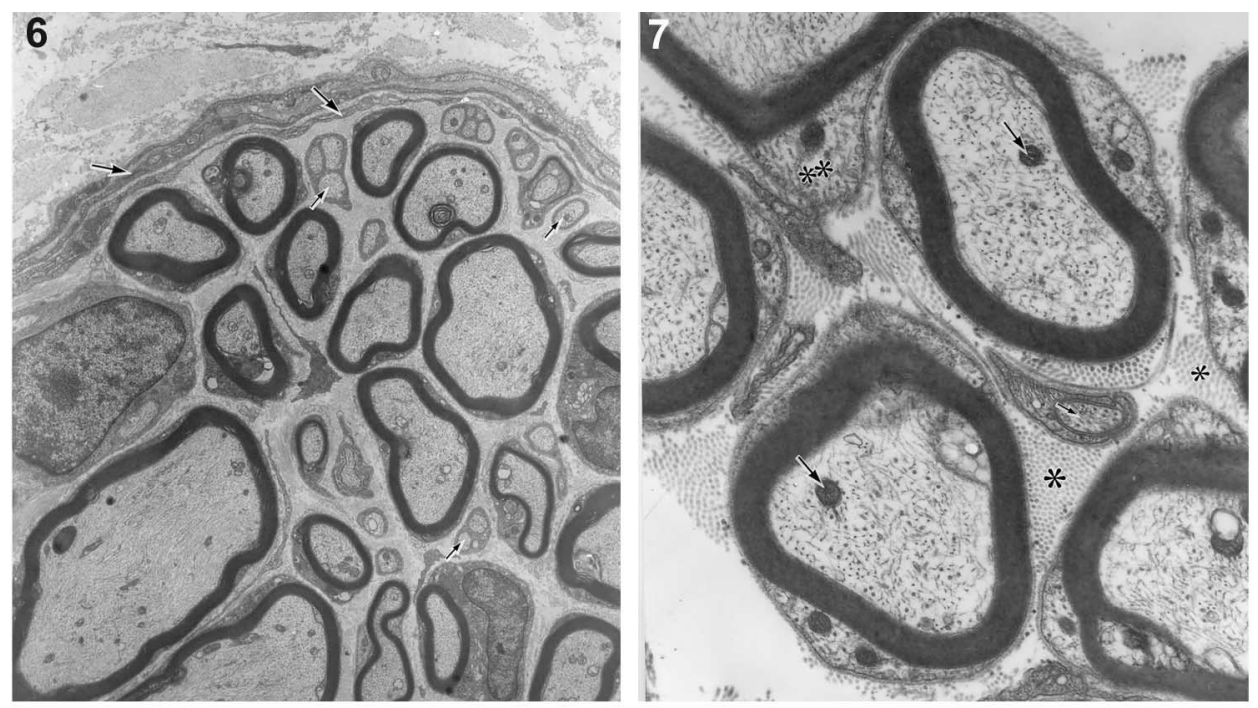

Fig. 6 TEM image revealing the bundles of nerve fibers with small and large diameters. The lamellae of perineural cell sheath (large arrows), unmyelinated fibers (small arrows) are evident. X2.500.

Fig. 7 TEM image of nerve fibers observe mitochondria (arrow), collagen fibers of endoneurium (*), and Schwann cell lamina (**). X4.400.

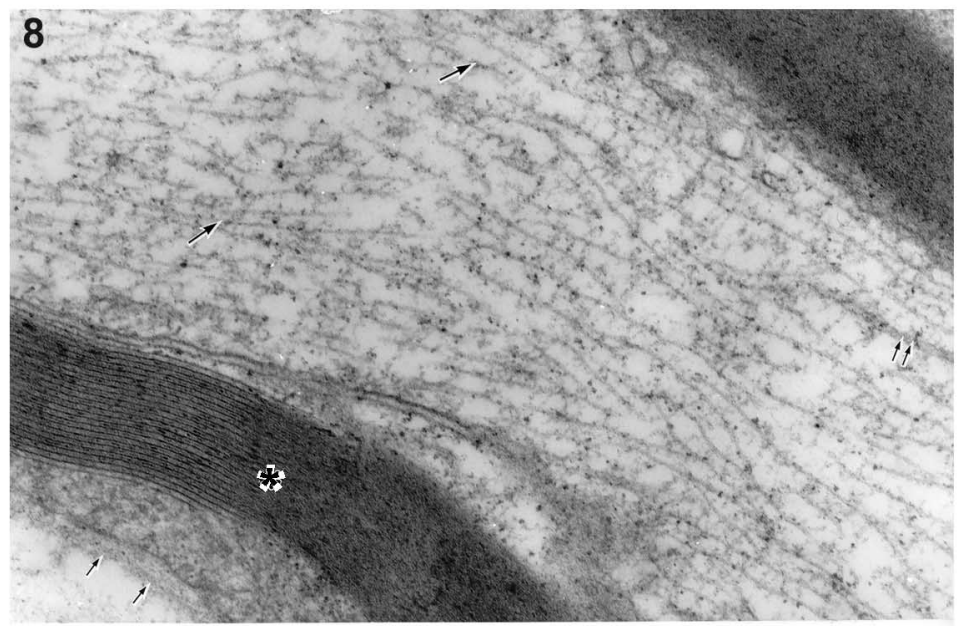

Fig. 8 Nerve fiber at high magnification showing myelin sheath characteristics $(*)$, basal lamina (small arrows), neurofilaments (large arrows). $\mathrm{X} 42.000$
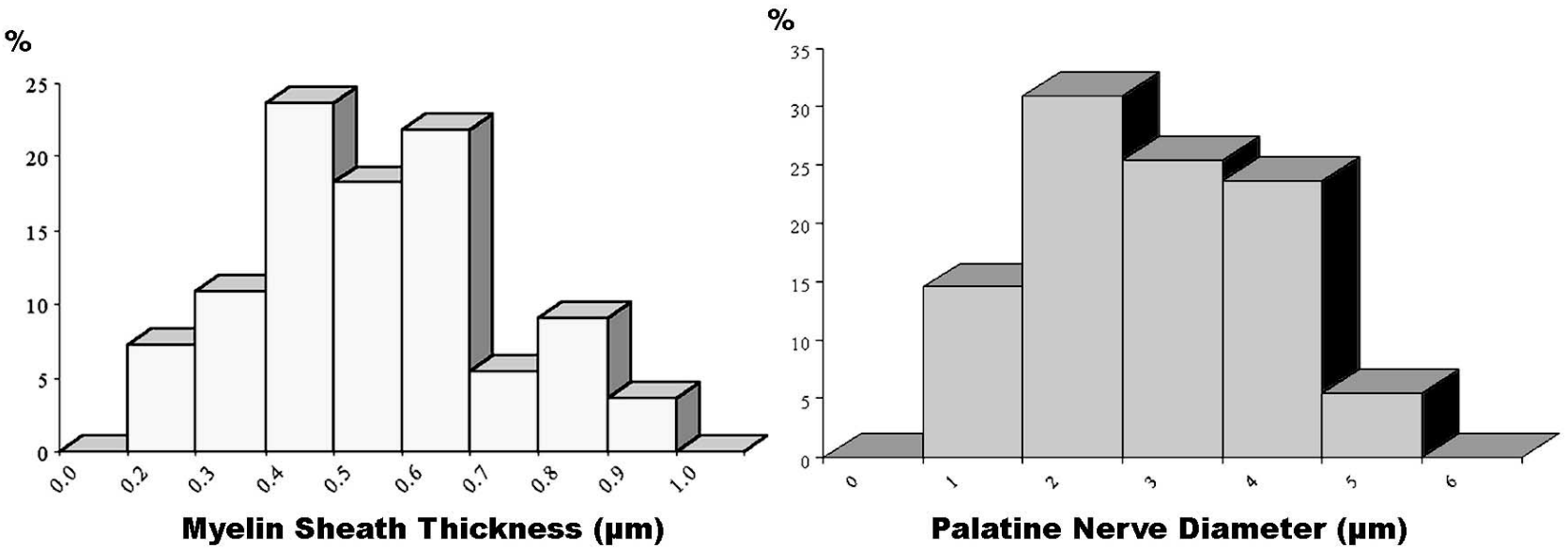

Table I Reveals the frequency of myelin sheath thickness.

Table II Reveals the frequency of palatine nerve diameter. 
TANISAKI, M.; OGAWA, K.; LAPA, S. R. C.; DA SILVA, P. M. C. \& WATANABE, I. Morphometric and high resolution scanning electron miccroscopic study of Calomys callosus major palatine nerve. Int. J. Morphol., 23(1):13-18, 2005.

RESUMEN: Se estudiaron las características del nervio palatino mayor del Calomys callosus, utilizando métodos de microscopía luz y electrónica de transmisión y de barrido de alta resolución. En el caso de microscopía de luz las muestras se fijaron con solución fijadora de Bouin, se trabajaron de la forma habitual y las secciones se tiñeron con hematoxilina-eosina y con azo-carmín para identificar las fibras nerviosas. En el caso de microscopía electrónica de alta resolución se utilizó el método O-D-O indicado por Tanaka (1989) para examinar los componentes de la fibra nerviosa y medir la vaina de mielina. Se examinaron secciones finas usando microscopio electrónico de transmisión para poner en evidencia los elementos axoplásmicos y las estructuras adyacentes. Los resultados demuestran la presencia de uniones de la fibra nerviosa en la lámina palatina de la mucosa de Calomys callosus. Las fibras nerviosas están envueltas en lamelas citoplasmáticas de células perineurales y uniones de colágeno adyacente y su diámetro varía de 1 a $6 \mu$ m; la vaina de mielina varía de 0.2 a $0.9 \mu \mathrm{m}$. En el axoplasma de las fibras nerviosas se observaron neurofilamentos, mitocondrias y neurotúbulos y se encontraron unas pocas fibras sin mielina.

PALABRAS CLAVE: Nervio palatino mayor; Microscopia electrónica de barrido de alta resolución; Microscopía electrónica de transmisión; Calomys callosus; Vaina de mielina; Morfometría.

\section{REFERENCES}

Foley, J. O. Functional components of the greater superficial petrosal nerve. Proc. Soc. Exp. Biol. Med., 64:15864, 1947.

Gairns, F.W. Sensory nerve endings in the human palate. $J$. Physiol., 123(2):26-7, 1954.

Gairns, F.W. The sensory nerve endings in the human palate. Q. J. Exp. Physiol. Cogn. Med. Sci., 40(1): 40-8, 1955.

Kubota, K. \& Hayama, S. Comparative anatomical and neurohistological observations on the tongues of Pigmy and common marmosets. Anat. Rec., 150:473-85, 1964.

Kubota, K. \& Togawa, S. Comparative anatomical and neurohistological observations on the tongue of Japanese dormouse (Glirus japonicus). Anat. Rec., 154(3):545-52, 1966.

Kubota, K. Comparative anatomical and neurohistological observations on the tongue of Japanese pika (Ochotona hyperborea). Anat. Rec., 154(1):1-12, 1966.

Kubota, K.; Kubota, J.; Fukuda, N.; Asakura, S. \& Nakagawa, S. Comparative anatomical and neurohistological observations on the tongue of the marsupials. Anat. Rec., 147:337-53, 1963.

Ogasawara, N.; Abe, Y. \& Sato, H. Innervation of the hard palate in cat and hedgehog. Tohoku J. Exp. Med., 59(4): 371-8, 1954.

Ohgaki, M. Innervation especially sensory innervation of facies inferior linguae in human adult. Tohoku J. Exp. Med., 57(2-3):157-67, 1953.

Shimozawa, A. An electron microscope analysis of the nerve of the pterygoid canal in the mouse. Anat. Rec., 175(3):631-7, 1973.

Shimozawa, A. Quantitative studies of the deep petrosal nerve of the mouse with the electron microscope. Anat. Rec., 172(3):483-8, 1972.

Shimozawa, A. Quantitative studies of the greater petrosal nerve of the mouse with the electron microscope. Anat. Rec., 170(3):303-8, 1971.

Tanaka, K. High resolution scanning electron microsocpy of the cell. Cell Biol., 65(2):89-98, 1989.

Watanabe, I. \& Konig Jr., B. Innervation of the palatine mucous membrane in the Cebus apella monkey. Tohoku J. Exp. Med., 123(3):215-20, 1977.

Watanabe, I. \& Yamada, E. Fine structure of lamellated nerve endings found in rat gingiva. Arch. Hist. Jap., 46:17382, 1983.

Watanabe, I. \& Yamada, E. Light and electron microscopy study of lamellated nerve endings found in rat cheek mucosa. Arch. Hist. Jap., 48:497-504, 1985.

Watanabe, I. Ultra-estrutura das fibras nervosas do nervo alveolar inferior de camundongos. Rev. Paul. Odont., 3: 12-6, 1981. 
Watanabe, I.; Jin, C. \& Nagata, T. Field Emission SEM, conventional TEM and HVTEM study of submandibular gland in prenatal and postnatal aging mouse. Histol. Histopathol., 12(2):447-57, 1997.

Watanabe, I.; Koriyama, Y. \& Yamada, E. High resolution scanning electron microscopic study of the mouse submandibular salivary gland. Acta Anat., 143(1):59-66, 1992.

Watanabe, I.; Seguchi, H.; Okada, T.; Kobayashi, T.; Jin, Q. S. \& Jiang, X. D. Fine structure of the acinar and duct cell components in the parotid and submandibular salivary glands of the rat: a TEM, SEM and HRSEM study. Histol. Histopathol., 11(1):103-10, 1996.
Correspondence to: Prof. Dr. Ii-sei Watanabe Department of Anatomy Institute of Biomedical Sciences University of São Paulo

Av. Prof. Lineu Prestes, 2415 CEP 05508-000

São Paulo, SP

BRAZIL

Tel. 3091-7386. Fax: 3091-7366

E-mail:watanabe@icb.usp.br

Recibido : 24-10-2004

Aceptado: 12-12-2004 